\title{
Factors Relating To Technology Integration in Education by the Pre-Service and the In-Service Teachers
}

\author{
Upasana Singh \\ Assistant Professor, Department of Education, Patna Women's College, Patna, Bihar, India
}

\begin{abstract}
Bihar is one of the rapidly progressing states of India. However, when on one hand it has emerged as the fastest growing state for the second year running, clocking a scorching 13.1\% growth in 2011-12, on the other hand the Gross Enrolment Ratio in both school as well as college education is still much lower here than in many other states of India. As such the Government and other public and private institutions of learning are making a concerted effort to provide technology enabled teaching-learning to increase the access to education, modernize it and bring the education system at par with that of the rest of the states as well as the global system. The present study focuses on four important factors related with the integration of technology in the teachinglearning process by the pre-service and the in-service teachers. These include their technology proficiency, the technology integration done by their faculty, their attitude towards the impact of technology on improving learning and the relationship between the three. The study is quantitative in nature and was conducted on a sample of pre-service and in-service teachers of Patna district of Bihar, India; collected by multistage cluster sampling technique.
\end{abstract}

Keywords: attitude, faculty integration of technology, in-service teachers, pre-service teachers and technology integration

\section{Introduction}

In the eleventh Five year plan, India moved from an 'elite' system of higher education to a 'mass' system in order to increase the Gross Enrolment Ratio (GER). Emphasizing the holistic system of education, the twelfth plan talks about expansion, access, equity and excellence in higher education by bringing higher education in India in line with and at the frontiers of global trends in higher education and knowledge development. (Planning Commission Report, 2012). One of the significant features of the ever-evolving system of education worldwide is the large-scale use of technology, resulting is up-to-date, uninterrupted, limitless supply of information to the students within a short span of time. However higher education cannot grow to touch the global frontiers unless grass-root changes are brought about in the school education. This requires the teachers to be technology-literate and able to integrate technology in the teaching-learning process as and when required. Since the future of the teachers is shaped in the teacher education institutions, technology-integrated education must be provided to the pre-service or prospective teachers. In this context Scheffler and Logan (1999) emphasized that integrating technology consists of a process in which learners try, fail, access, evaluate, analyse and apply meaningful tasks including but not limited to researching, analyzing data, applying and representing knowledge, communication and collaborating. In educational uses of technology, Jonassen and Reeves (1996) make a distinction between learning from technology and learning with technology. Means and Olson (1997) found that technology increased the complexity with which students could deal successfully and created a multiplicity of roles, leading to student specialization. There is evidence that technology is changing the way instructors are teaching in their classes. Educators have been under pressure to reform schools through technology (Becker, 2001; Mehlinger, 1996; Sheingold \& Hadley, 1990). However, there is an alarming gap between technology's presence and its effective integration into classroom instruction (Bryant, 2000; Cuban, 2001). Technology has the potential for changing the way teachers teach and students learn. (Thompson, Schmidt, \& Davis, 2003), but research indicates that educators are less likely to use computers than other professions (Hanushek, 1998). In addition, teachers play a major role in how successful technology will be in education (Yildirim \& Kiraz, 1999). Thus it can be said that technology, if and when integrated strategically and pragmatically with pedagogy, leads to significant results in the education system. Effective technology integration in education by the pre-service and the in-service teachers depends on four main factors, viz., their proficiency in using different technological applications for instructional activities, frequency of technology integration done by their faculty, their attitude towards the impact of technology integration on improving learning and the mutual relationship between these three. It is to study these factors that the present study was undertaken. 


\section{Objective of the Study}

The study was conducted with the objective to determine the extent to which the technology proficiency of the pre-service and the in-service teachers and the frequency of their faculty integration of technology in instructional activities predict their attitude towards the impact of technology integration on improving learning.

\subsection{Design of the Study}

III. Method

This study was a descriptive sample survey conducted on two teacher education institutions and four private schools of Patna, two affiliated to the Central Board of Secondary Education (CBSE) and the other two affiliated to Indian Certification of Secondary Education (ICSE Board).

\subsection{Population and sample of the study}

The population frame of the study comprised the pre-service teachers of all the teacher education institutions of Patna University and the in-service teachers of all the private schools of Patna district of Bihar. A sample of 150 pre-service teachers and 64 in-service teachers was selected by Multistage Cluster Sampling technique.

\subsection{Tool of the study}

Technology Integration Questionnaire (TIQ) for pre-service teachers and in-service teachers was prepared. The items sought information related to demographic variables, proficiency in using various tools/devices and software application for personal and professional uses, frequency of faculty integration of technology for instructional activities and the attitude of pre-service and in-service teachers towards the impact of technology integration on improving learning. All the sections of TIQ had a Cronbach alpha value ranging from 0.73 to 0.93 and were therefore within the acceptable range. Content validity was established with the help of experts.

Table 1: Cronbach alpha values for different sections

\begin{tabular}{|l|l|l|}
\hline Section & No. of items & Alpha value \\
\hline For pre-service teachers & 12 & 0.78 \\
\hline Tool/device proficiency & 20 & 0.83 \\
\hline Software proficiency & 17 & 0.93 \\
\hline $\begin{array}{l}\text { Frequency of faculty technology } \\
\text { integration }\end{array}$ & 24 & 0.75 \\
\hline Pre-service attitude & 12 & 0.76 \\
\hline For in-service teachers & 20 & 0.80 \\
\hline Tool/device proficiency & 17 & 0.88 \\
\hline Software proficiency & 24 & 0.73 \\
\hline $\begin{array}{l}\text { Frequency of faculty technology } \\
\text { integration }\end{array}$ & \multicolumn{2}{|l|}{} \\
\hline In-service attitude &
\end{tabular}

\subsection{Analysis of the data}

\section{Analysis of the Data and Related Findings}

The data was analysed using statistical techniques such as percentages, measures of central tendency and dispersion, scatter plots and regression coefficients and inferential statistic such as t-test. Software packages such as SPSS and R were used for data analysis.

4.1.1 Comparison of proficiency of the pre-service and the in-service teachers in using technology Table 2a: Group statistics for proficiency

\begin{tabular}{|l|l|l|l|l|}
\hline \multicolumn{1}{|c|}{ Group } & N & Mean & Std. Deviation & Std. Error Mean \\
\hline $\begin{array}{l}\text { Technology proficiency of pre-service } \\
\text { teachers }\end{array}$ & 150 & 32.02 & 7.851 & 0.641 \\
\hline $\begin{array}{l}\text { Technology proficiency of in-service } \\
\text { teachers }\end{array}$ & 64 & 55.67 & 18.862 & 2.358 \\
\hline
\end{tabular}


Table 2b: Independent samples t-test for proficiency

\begin{tabular}{|c|c|c|c|c|c|c|}
\hline & & \multicolumn{5}{|c|}{$\begin{array}{l}\text { Levene's Test for } \\
\text { Equality of Variances }\end{array} \mid$-test for Equality of Means } \\
\hline & & $\mathbf{F}$ & Sig. & $t$ & df & Sig. (2-tailed) \\
\hline \multirow{2}{*}{$\begin{array}{l}\text { Technology } \\
\text { Proficiency }\end{array}$} & \begin{tabular}{|l} 
Equal \\
variances \\
assumed
\end{tabular} & 83.961 & 0.000 & -12.976 & 212 & 0.000 \\
\hline & \begin{tabular}{|ll} 
Equal & \\
variances & not \\
assumed &
\end{tabular} & & & -9.680 & 72.489 & 0.000 \\
\hline
\end{tabular}

From the above two Tables ( $2 \mathrm{a}$ and $2 \mathrm{~b}$ ), it can be inferred that that there is a significant difference between the pre-service and the in-service teachers as regards their technology proficiency; the in-service teachers being more proficient. This can be ascribed to the opportunities and curricular practices prevailing in the private schools which hone the technology skills already possessed by them. In teacher education institutions, students from diverse background and disciplines take admission; all of whom are not so proficient in using technology.

4.1.2 Comparison of the Frequency of Faculty Integration of Technology of the Pre-Service and the InService Teachers

Table 3a: Group statistics for frequency of faculty integration of technology

\begin{tabular}{|c|c|c|c|c|}
\hline Group & $\mathbf{N}$ & Mean & Std. Deviation & $\begin{array}{c}\text { Std. Error } \\
\text { Mean }\end{array}$ \\
\hline $\begin{array}{c}\text { Frequency of faculty integration of } \\
\text { technology-pre-service teachers }\end{array}$ & 150 & 30.16 & 10.134 & 0.827 \\
\hline $\begin{array}{c}\text { Frequency of faculty integration of } \\
\text { technology-in-service teachers }\end{array}$ & 64 & 20.64 & 6.380 & 0.798 \\
\hline
\end{tabular}

Table 3b: Independent samples t-test for frequency of faculty integration of technology

\begin{tabular}{|c|c|c|c|c|c|c|}
\hline \multicolumn{2}{|c|}{} & $\begin{array}{c}\text { Levene's Test for } \\
\text { Equality of } \\
\text { Variances }\end{array}$ & \multicolumn{3}{|c|}{ t-test for Equality of Means } \\
\hline & $\begin{array}{c}\text { Equal } \\
\text { variances } \\
\text { assumed }\end{array}$ & 15.655 & 0.000 & 6.945 & 212 & 0.000 \\
\cline { 2 - 8 } $\begin{array}{c}\text { Frequency of faculty } \\
\text { integration of technology }\end{array}$ & $\begin{array}{c}\text { Equal } \\
\text { variances not } \\
\text { assumed }\end{array}$ & & & 8.283 & $\begin{array}{c}182.30 \\
5\end{array}$ & 0.000 \\
\hline
\end{tabular}

The above two Tables ( $3 \mathrm{a}$ and $3 \mathrm{~b}$ ) clearly indicate that there is a significant difference between the faculty integration of technology for instructional purposes for the pre-service and the in-service teachers; it being higher for the faculty of pre-service teachers. This is quite evident when we observe the Figs. given below, showing the age groups to which the pre-service and the in-service teachers belong. 


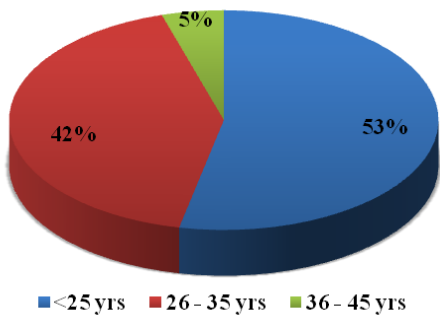

Figure 1: age group of pre-service teachers

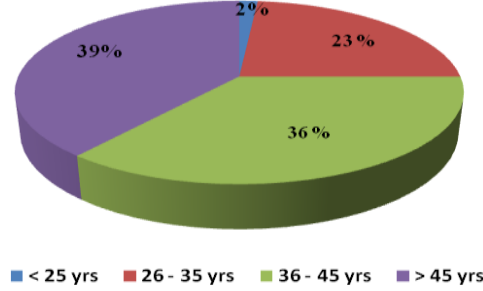

Figure 2: age group of in-service teachers

It is clear from the two Figs.(1 and 2) that a majority of the in-service teachers were above 45 years of age and only $2 \%$ of them were below 25 years of age. However, the maximum percentage of pre-service teachers was below 25 years of age When these in-service teachers were students, the use of technology was rare in the field of education. Consequently, there was lesser faculty integration of technology for instructional activities by their faculty. Today when technology is gradually becoming an integral part of teaching-learning, definitely the faculty integration of technology has incrased.

4.1.3 Comparison of attitude of the pre-service and the in-service teachers towards the impact of technology integration on improving learning

Table 4a: Group statistics for attitude towards the impact of technology integration on improving learning

\begin{tabular}{|l|l|l|l|l|}
\hline Group & $\mathbf{N}$ & Mean & Std. Deviation & Std. Error Mean \\
\hline Attitude of pre-service teachers & 150 & 88.35 & 10.478 & .856 \\
\hline Attitude of in-service teachers & 64 & 87.14 & 14.645 & 1.831 \\
\hline
\end{tabular}

Table 4b: Independent samples t-test for attitude towards the impact of technology integration on improving learning

\begin{tabular}{|c|c|c|c|c|c|c|}
\hline & & \multicolumn{2}{|c|}{$\begin{array}{l}\text { Levene's Test } \\
\text { for Equality of } \\
\text { Variances }\end{array}$} & \multicolumn{2}{|c|}{$\begin{array}{l}\text { t-test for } \\
\text { Means }\end{array}$} & Equality of \\
\hline & & $\mathbf{F}$ & Sig. & $t$ & df & $\begin{array}{l}\text { Sig. } \\
\text { tailed) }\end{array}$ \\
\hline \multirow{2}{*}{$\begin{array}{l}\text { Attitude towards the impact of } \\
\text { technology integration on improving } \\
\text { learning }\end{array}$} & $\begin{array}{l}\text { Equal } \\
\text { variances } \\
\text { assumed }\end{array}$ & 5.633 & .019 & 0.681 & 212 & 0.497 \\
\hline & \begin{tabular}{ll|} 
Equal \\
variances not \\
assumed
\end{tabular} & & & 0.597 & 91.675 & 0.552 \\
\hline
\end{tabular}

Tables $4 \mathrm{a}$ and $4 \mathrm{~b}$ show that the pre-service and the in-service teachers do not differ significantly in their attitude towards the impact of technology integration on improving learning.

Table 4c: Overall attitude towards the impact of technology integration on improving learning

\begin{tabular}{|c|c|c|c|}
\hline & $\begin{array}{c}\text { Strongly } \\
\text { agree }\end{array}$ & Agree & Disagree \\
\hline $\begin{array}{c}\text { Pre- } \\
\text { service }\end{array}$ & $76 \%$ & $16 \%$ & $8 \%$ \\
\hline $\begin{array}{c}\text { In- } \\
\text { service }\end{array}$ & $68 \%$ & $16 \%$ & $16 \%$ \\
\hline
\end{tabular}

From Table 4c, it is found that $76 \%$ of the pre-service teachers and $68 \%$ of the in-service teachers strongly agree that technology integration in teaching-learning leads to improvement in learning while only $8 \%$ and $16 \%$ of them respectively disagree with it. Thus it can be inferred that both the pre-service and the in-service teachers have a positive attitude towards the impact of technology integration on improving learning. 
Both of them feel that if technology is integrated in the teaching-learning process, it will impact the learning outcomes in the positive direction.

4.1.4 prediction of the attitude of the pre-service and the in-service teachers towards the impact of technology integration on improving learning from their technology proficiency and the frequency of their faculty integration of technology in instructional activities

\subsubsection{1 for the pre-service teachers}

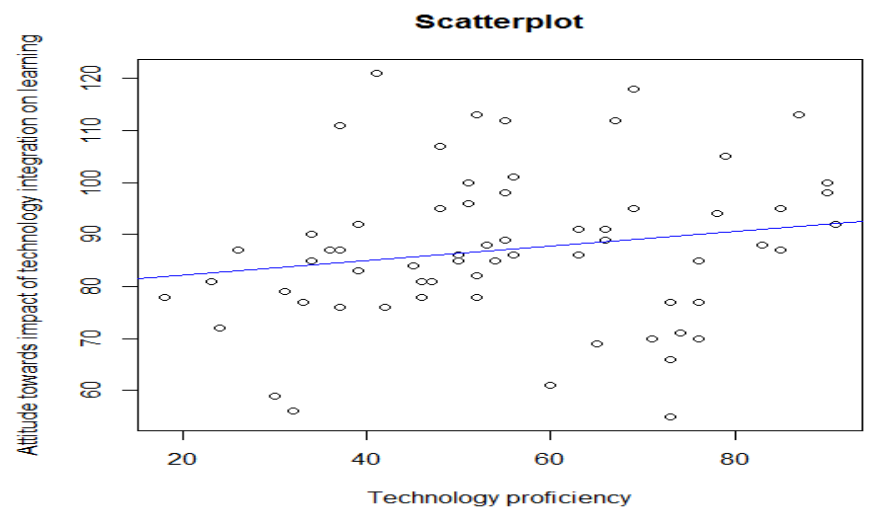

Figure 3: scatter plot between attitude of the pre-service teachers towards the impact of technology integration on improving learning and their technology proficiency

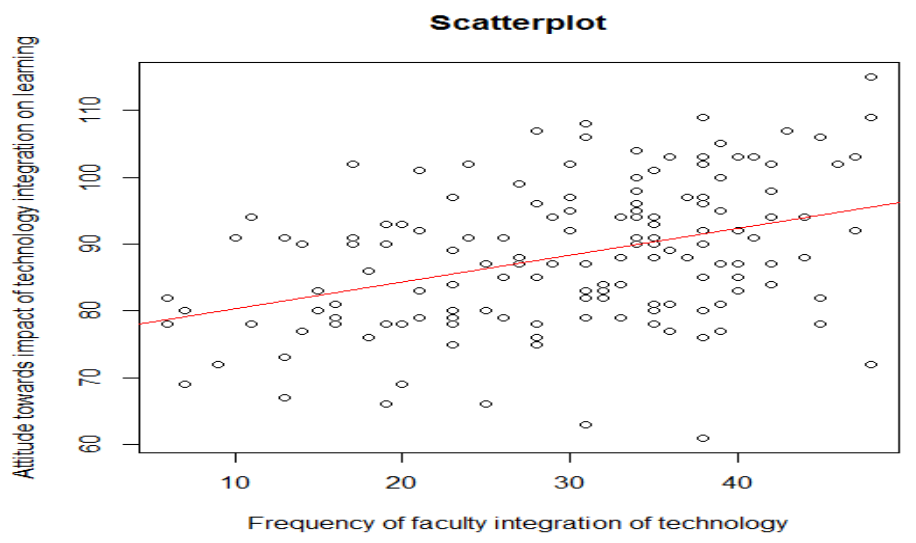

Figure 4: scatter plot between attitude of the pre-service teachers towards the impact of technology integration on improving learning and frequency of their faculty integration of technology

The scatter plot in Fig. 3 shows that regression line between the technology proficiency of pre-service teachers and their attitude towards the impact of technology integration on improving learning is positive but not very steep. Thus, as technology proficiency of the pre-service teachers increases, their attitude becomes more positive, however the relationship is not very strong. The regression line of the scatter plot in Fig. 4 between their faculty integration of technology and the attitude of pre-service teachers towards the impact of technology integration on improving learning is also positive and slightly steeper than the previous regression line, suggesting that the relationship between the attitude and faculty integration of technology is stronger than that between the attitude and technology proficiency of the pre-service teachers. 


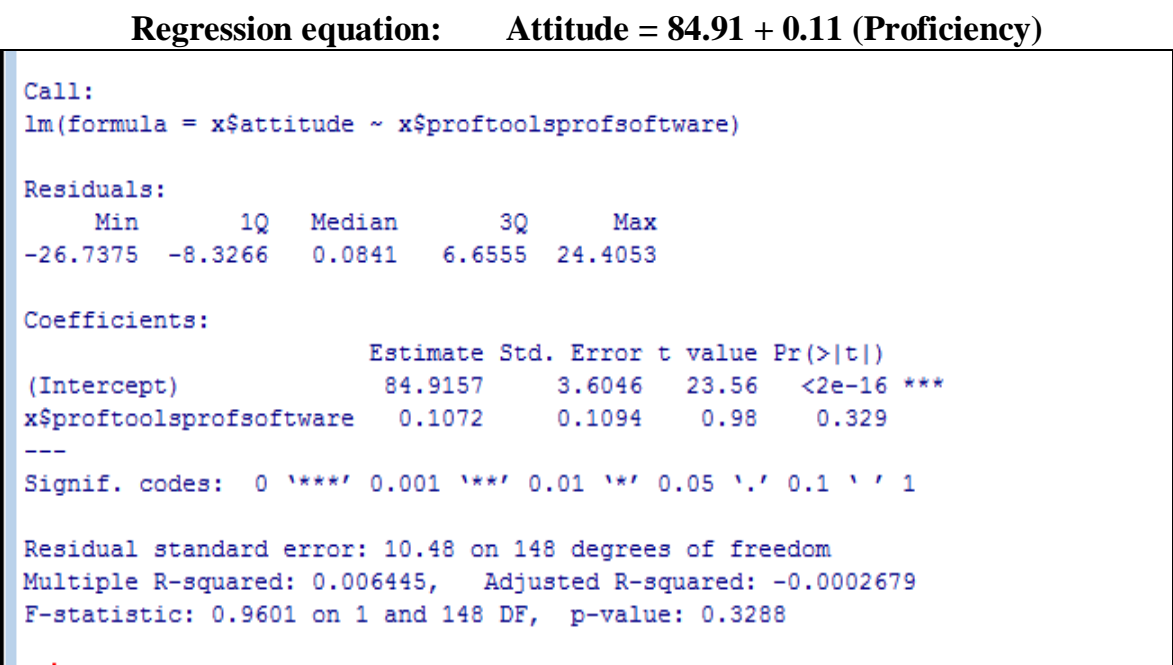

Figure 5: Prediction of attitude of the pre-service teachers towards the impact of technology integration on improving learning from their technology proficiency

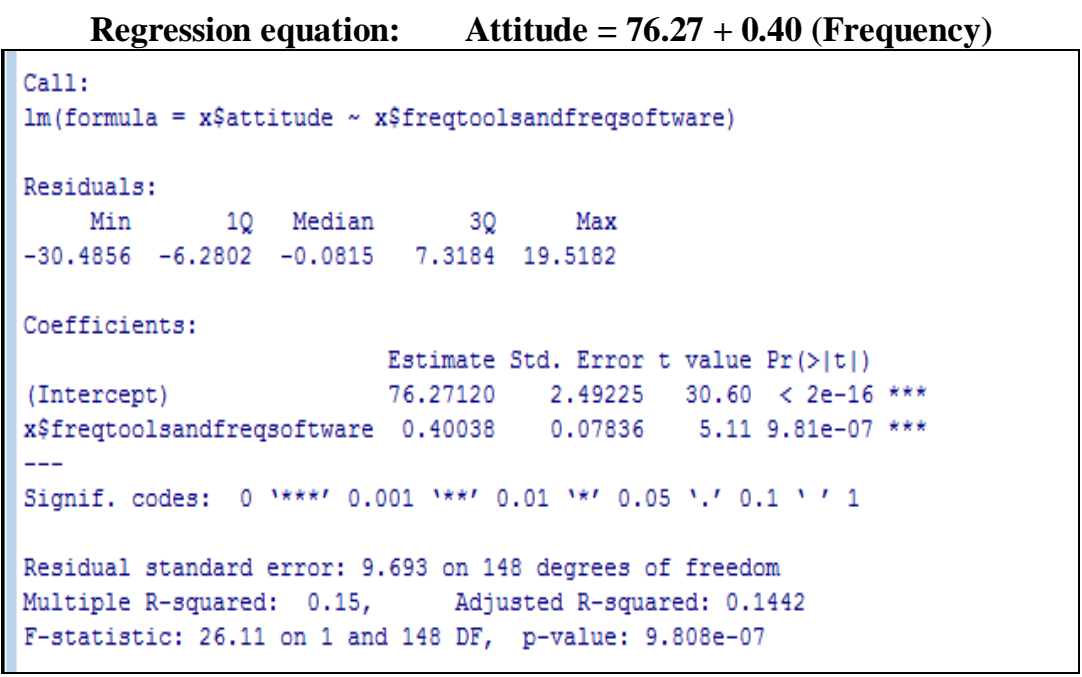

Figure 6: Prediction of attitude of the pre-service teachers towards the impact of technology integration on improving learning from the frequency of their faculty integration of technology

The regression equation in Fig.5 indicates that the predicted score in attitude when technology proficiency of the pre-service teachers is equal to zero is 84.91 and for one unit increase in technology proficiency, an increase of 0.11 can be predicted on the attitude scale. The value of multiple R-squared shows that $0.64 \%$ of the variance in attitude can be explained by the technology proficiency of pre-service teachers which is not at all significant. The regression equation in Fig. 6 depicts that the predicted score in attitude when no faculty integration of technology is there is 76.27 and an increase of 0.40 on the attitude scale can be predicted for one unit increase in the faculty integration of technology in teaching-learning. Both the values are significant. Also, a variance of $15 \%$ can be explained in attitude by the faculty integration of technology of the pre-service teachers. In this way it is seen that the relationship between attitude and faculty integration of technology is much stronger than the relationship between attitude and technology proficiency. 


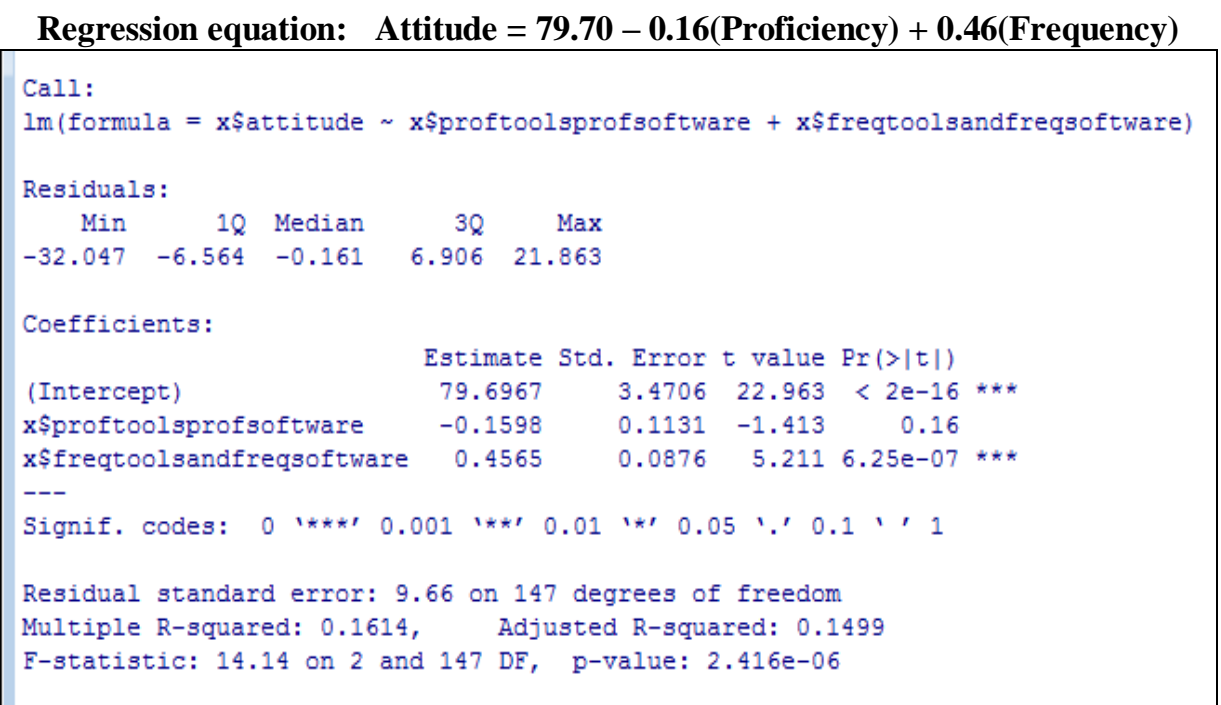

Figure 7: Prediction of attitude of the pre-service teachers towards the impact of technology integration on improving learning from their technology proficiency and the frequency of their faculty integration of technology taken together

The regression equation in Fig. 7 clearly suggests that the faculty integration of technology in the instructional activities is a much stronger predictor of the attitude of the pre-service teachers towards the impact of technology integration on improving learning than their technology proficiency. In its presence the slope of technology proficiency becomes negative; however its value is not significant. The value of multiple R-squared shows that about $16 \%$ of the variance in attitude can be explained by the two predictor variables taken together.

\subsubsection{2 for the in-service teachers}

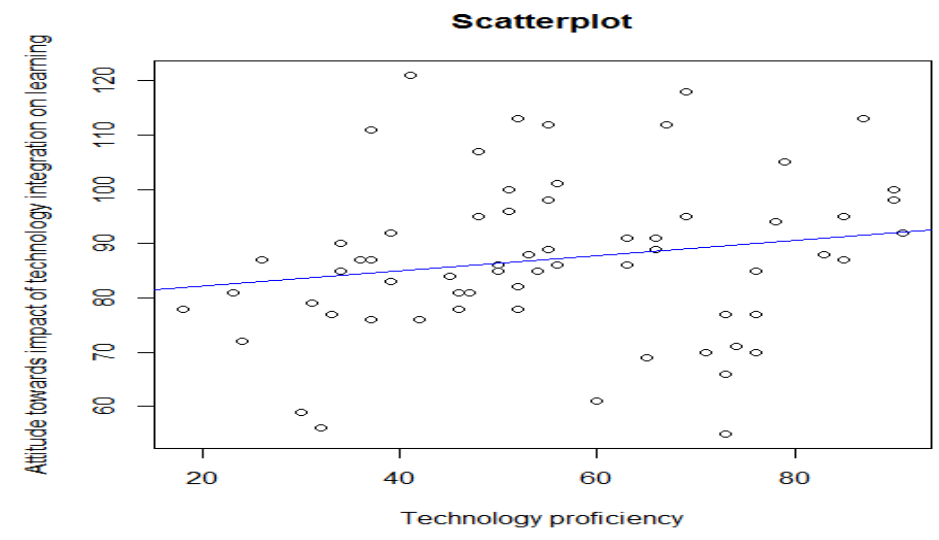

Figure 8: scatter plot between attitude of the in-service teachers towards the impact of technology integration on improving learning and their technology proficiency 


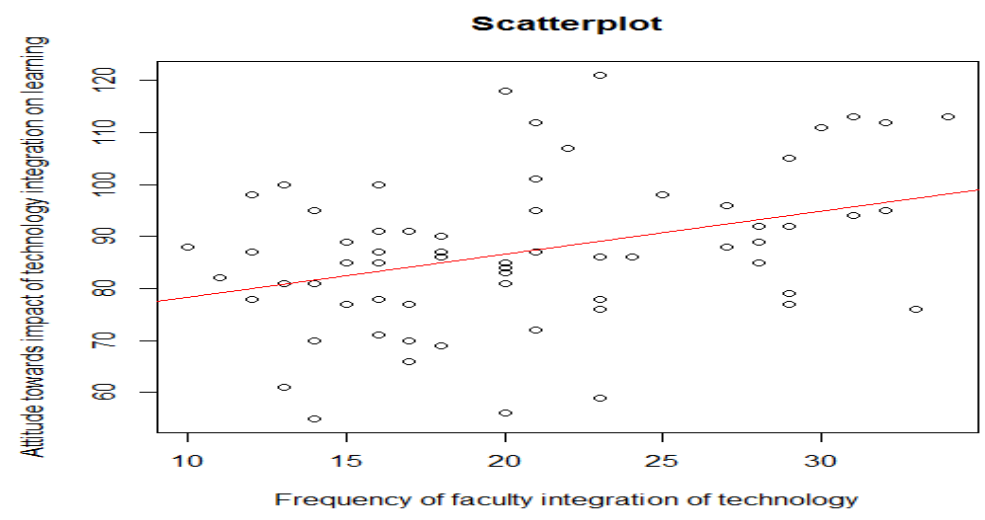

Figure 9: scatter plot between attitude of the in-service teachers towards the impact of technology integration on learning and the frequency of their faculty integration of technology

The scatter plot in Fig. 9 has a much steeper regression line than the scatter plot in Fig. 8. This is the same as the case of the pre-service teachers. These plots suggest a stronger relationship between the attitude of the in-service teachers towards the impact of technology integration on improving learning and their faculty integration of technology for instructional activities than that between the attitude and the technology proficiency of the in-service teachers.

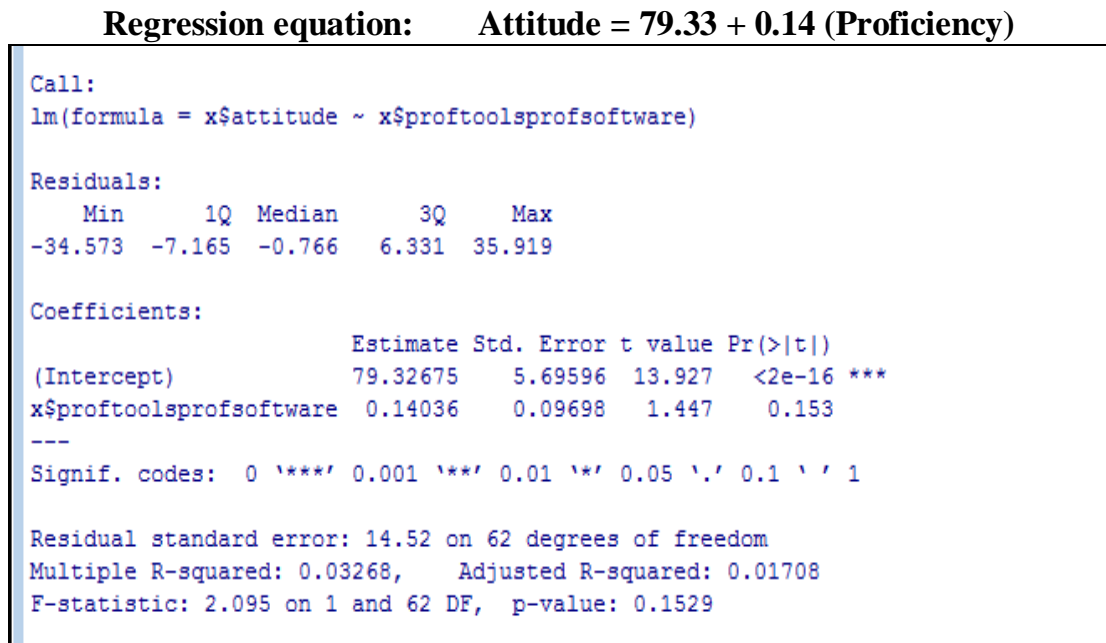

Figure 10: Prediction of attitude of the in-service teachers towards the impact of technology integration on improving learning from their technology proficiency 


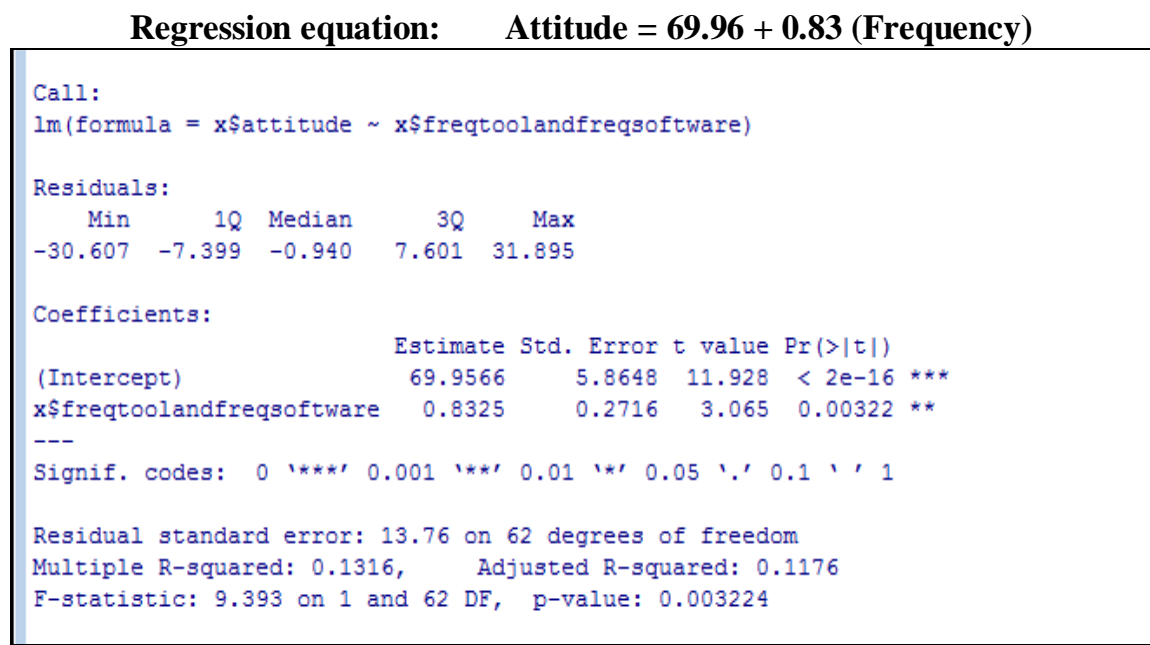

Figure 11: Prediction of attitude of the in-service teachers towards the impact of technology integration on improving learning from the frequency of their faculty integration of technology

The regression equation in Fig.10 clearly depicts that for one unit increase in the technology proficiency of the in-service teachers, an increase of only 0.14 can be predicted on the attitude scale and just $3 \%$ of the variance in attitude can be explained by the technology proficiency of the in-service teachers. Both these values are quite low. However, Fig. 11 indicates that an increase of 0.83 can be predicted on the attitude scale per one unit increase in faculty integration of technology of the in-service teachers. The value of multiple R-squared shows that $13 \%$ of the variance in attitude can be explained by the faculty integration of technology. Thus, in the case of in-service teachers also, the relationship between the attitude and faculty integration of technology is much stronger than the relationship between attitude and technology proficiency.

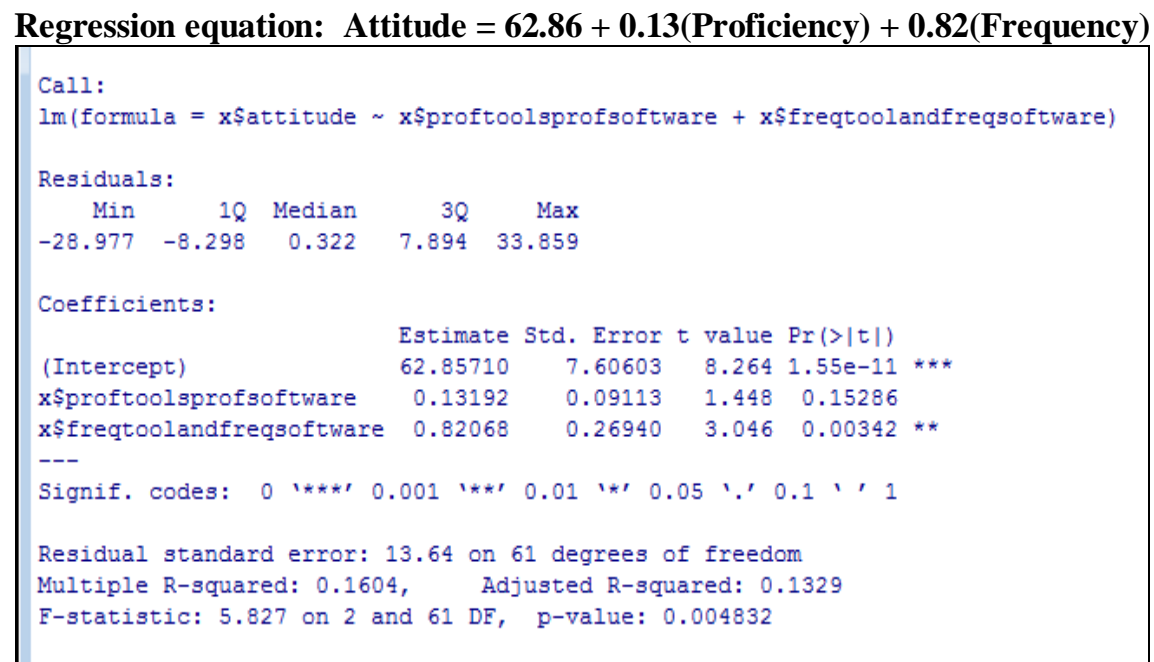

Figure 12: Prediction of attitude of the in-service teachers towards the impact of technology integration on improving learning from their technology proficiency and the frequency of their faculty integration of technology taken together

The stronger relationship between the attitude of the in-service teachers towards the impact of technology integration on improving learning and their faculty integration of technology than that between attitude and the technology proficiency of the in-service teachers is evident from the regression equation in Fig. 12.

\subsection{Findings of the study}

The findings of the study can be enumerated in the following points:

- The in-service teachers are more proficient in using technology for various instructional purposes than the pre-service teachers.

- The faculty members of the pre-service teachers integrate technology in teaching-learning more than that of the in-service teachers. 
- The pre-service and the in-service teachers do not differ significantly in their attitude towards the impact of technology integration on improving learning.

- Both of them have strong positive attitude regarding the improvement of learning through effective technology integration in the teaching-learning process.

- If the faculty integrates technology in the pedagogical process, then this positively affects the attitude of the pre-service and the in-service teachers towards the impact of technology integration on learning. This relationship is more pronounced than the relationship between their own proficiency in using technology in teaching and learning.

\section{Conclusion}

In the present era, integration of technology in the pedagogical process can influence the educational system to its core. This can be effectively infused by the teachers. If we have technology proficient teachers who know when and how to use technology and to what extent, it will not only procure desirable learning outcomes at par with the global trends but also help in developing positive attitude towards technology usage among their students. The Government has to ensure that knowledge about the upcoming technologies and training in them is provided to the teachers time and again to polish their skills. At the same time, the administration, management and the teachers themselves have to come forth and make conscientious efforts to effectively and efficiently integrate technology in the educational transactions for knowledge creation and to meet the ever changing demands of the liberalized and globalized nation.

\section{Acknowledgements}

This paper is a part of the Minor Project titled 'Assessment of Technology Integration among Pre-service and In-service Teachers' funded by the University Grants Commission (UGC), New Delhi, India. I am thankful to UGC for approving the proposal and providing the monetary support. I express my gratitude to the Principal of Patna Women's College, Dr. Sr. Doris D'Souza A.C. for permitting me to do the project without any hindrance. I am indebted to Mr. Sudhir Kumar Singh, Director, BST Education, Patna for helping me in collecting and analyzing data for my work.

\section{References}

[1] Planning Commission Report, XIIth Five Year Plan, Planning Commission of India, New Delhi, 2012.

[2] F. Scheffler and J. Logan, Computer technology in schools: What teachers should know and be able to do, Journal of Research on Computing in Education, 31, 1999, 305-325.

[3] D.H. Jonassen and T. Reeves, Learning with computers: Computers as cognitive tools, in D.H. Jonassen (Ed.), Handbook of research for educational communications and technology, (New York: MacMillan, 1996) 693-719.

[4] B. Means and K. Olson, Technology and education reform (Washington, DC:U.S., 1997).

[5] H.J. Becker, How are teachers using computers in instruction? Paper presented at the 2001 meeting of the American Educational Research Association, 2001, Retrieved from http://www.crito.uci.edu/tlc/FINDINGS/special3/

[6] H.D. Mehlinger, School reform in the information age. Phi Delta Kappan, 1996, 400-407.

[7] K. Sheingold and M. Hadley, Accomplished teachers: Integrating computers into classroom practices (New York: NY, 1990).

[8] A.L. Bryant, Investment in education and technology: The key to preparing for the digital age, in Technos: Quarterly for Education and Technology, Winter, 2000, Retrieved from http://www.findarticles.com/cf_dls/m0HKV/4_9/68951437/p1/article.jhtml.

[9] L. Cuban, Oversold and underused: Computers in the classroom (Cambridge, MA: Harvard University Press, 2001).

[10] A.D. Thompson, D.A. Schmidt and N.E. Davis, Technology collaborative for simultaneous renewal in teacher education, Educational Technology, Research and Development, 51(1), 2003, 73-89.

[11] E.A. Hanushek, Outcomes, incentives and beliefs: Reflections on analysis of the economics of schools, Educational Evaluation and Policy Analysis, 19(4), 1998, 301-304.

[12] S. Yildirim and E. Kiraz, Obstacles to integration of on-line communication tools into preservice teacher education, Journal of Computing in Teacher Education, 15(3), 1999, 23-28. 